\title{
Jiná podoba př́běhu o osamělosti v televizním seriálu Olive Kitteridgeová
}

Petr Bubeníček

\begin{abstract}
Olive Kitteridge - a new take on the narrative of loneliness

The study focuses on the adaptation of Elizabeth Strout's novel Olive Kitteridge. The socio-psychological novel and the HBO produced TV series gained the favour of readers, critics, and viewers alike. The study considers the ways in which the TV series utilizes approaches typical for "quality TV": disturbing the limits of the given genre, evoking darker mindsets, inhabiting the story-world with morally ambivalent characters, and uncovering the roots of economic, political, and social decay of postindustrial society.
\end{abstract}

\section{KEYWORDS}

Novel, TV series, adaptation.

\section{KLÍčOVÁ SLOVA}

Román, televizní seriál, adaptace.

Román spisovatelky Elizabeth Stroutové Olive Kitteridgeová vyšel v roce 2008 (do češtiny byl přeložen v roce 2010), dočkal se mimořádného čtenářského ohlasu a získal řadu ocenění, především Pulitzerovu cenu (2009). Kniha zaujala americkou filmovou herečku Frances McDormandovou do té míry, že iniciovala natočení stejnojmenné čtyřdílné televizní „minisérie“, stala se její spolutvůrkyní a producentkou a také v ní ztvárnila hlavní roli. Umělecky náročnější kvalita seriálu byla oceněna jeho nominací v berlínské soutěži Zlatý medvěd (společně s Temným př́padem, HBO, 2014; The Missing, BBC, 2014 a vítězným Fargem, FX Networks, 2014). Zaujal tedy místo mezi originálními televizními seriály vznikajícími v USA 
a v Evropě, které se svým vizuálním stylem přiblížily estetickým formám hraného filmu (THOMPSON 2003). Sociálně-psychologický román Stroutové (přeložený do řady jazyků, mimo jiné i japonštiny či arabštiny) i high-endový televizní seriál si získaly přízeň kritiky, čtenářro i diváků. Otázkou je, zda k tomu přispěla jejich sdělnost, v současné kultuře dominantní žánr vyprávění na pokračování či schopnost tvůrčího týmu nabídnout v obrazu nevelkého městečka na východním pobřeží Spojených států výpověd’ o lidské existenci v současném světě vůbec.

$\mathrm{Na}$ detailnější popis inovativních seriálů a jejich role v kultuře (jako zlom bývá označován vznik Městečka Twin Peaks, 1990, po němž následovala řada dalších seriálů přinášejících nové estetické inovace) není v této případové studii místo, podržíme se tedy alespoň několika základních vymezení tzv. quality TV (McCABE a AKASS 2007). V roce 1996 Robert Tompson spatřoval základní rysy kvalitního seriálu v tom, že diváka „vzdělává, obohacuje, klade na něj nároky, vtahuje jej a konfrontuje. Odvažuje se riskovat, je upřímný a poučný, apeluje na intelekt a dotýká se emocí. Vyžaduje koncentraci a pozornost a provokuje k zamyšlení" (TOMPSON 1996: 13, přel. PB). Quality TV je ovšem jev natolik komplexní, že si nevystačíme s popisem estetických ambicí stojících v kontrastu k mainstreamovým projevi̊m, komplikovaných vyprávěcích postupů, nejednoznačných motivací postav či odlišných strategií seriality. Badatelé zabývající se tímto fenoménem debatují o kánonu quality $T V$, produkčních podmínkách, vlivu kabelových stanic na etablování nových forem a žánrů či recepci a vztazích mezi fanoušky a producenty. Právě interakce s diváky je způsobem, jakým výrobci a distributoři kulturních obsahů reagují na aktuální soudy o kvalitě, čehož následně využívají při vytváření nových produktů. Obracejí se ke specifickému publiku, které často spojuje dobré vzdělání či vyšší společenský status. Tento trend trefně vyjadřují slova Simona Browna: „[...] kvalita byla kultem, protože nebyla součástí hlavního programu televizních stanic a byla vytvořena tak, aby přilákala speciální publikum, avšak velmi odlišné od té skupiny diváků, která se obvykle stává publikem kultovních produktů. Toto větší, kvalitnější publikum, sestávalo většinou ze členů střední třídy, dospělých, relativně majetných a s náročnějším vkusem“ (BROWN 2010: 157, přel. PB). Kvalita je tedy úspěšným prostředkem kulturního průmyslu sloužícím $\mathrm{k}$ naplňování produkčních cílů. Paradoxně se v tomto označení proplétají estetické soudy akademiků a kritiků s pragmatismem výrobců kulturních obsahů. Jason Mittel v knize Complex TV: The Poetics of Contemporary Television Storytelling (2015) připomíná, že pojem quality TV je mezi americkými vědci zabývajícími se televizí užívaný spíše zřídka pro svou nejednoznačnost i z toho důvodu, že mnozí z nich odmítají chápat televizi jako 
„estetický objekt“ (MITTEL 2015: 210). Mittel, přinášející pojem complex TV, si nicméně pokládá otázku, jak některé seriály dosahují estetického úspěchu a zabývá se „formálním rozměrem a kulturními praktikami současného televizního sériového vyprávění" (MITTEL 2015: 9 , přel. PB). ${ }^{1}$

Vznik televizního seriálu je složitě koordinovanou kolektivní činností, na jeho vzniku se podílí velké množství lidí. O výsledné podobě jeho dramatické stavby či o obsazení realizačního štábu vyjednávají výkonní producenti s režiséry a scenáristy podílejícími se na vzniku jednotlivých epizod. V konečném důsledku tak hlavní roli hrají právě výkonní producenti (projekt vedou tzv. showrunners) a stabilní tým scenáristů, zatímco ve filmu vyzdvihovaní režiséři jsou „často najímáni jako rotující pracovníci na volné noze“ (MITTEL 2015: 90). Zapojení širšího týmu do kreativních rozhodnutí odkrývá scenáristka Jane Andersonová, která po čtyřech měsících práce musela začít znovu a přijít s novou verzí scénáře: „Nakonec jsem prosila svého výkonného producenta: nemohla bych prostě odvykládat ten př́běh? Ale stejně jsem musela projít oním protivným procesem, kdy člověk roztrhá na kousíčky původní verzi a začne od konce“ (SOLLOSI 2014, cit. 27. 6. 2017, přel. PB). Olive Kitteridgeová byla financovaná kabelovou televizní stanicí HBO. Existuje mnoho důvodů pro vzestup quality TV - zaměření amerického filmového průmyslu primárně na trháky, menší tržby filmových studií, rozvoj domácí zábavy a s tím spojená menší návštěvnost kin, přesun spisovatelů a scenáristů $\mathrm{k}$ televiznímu vysílání - přičemž kabelové televize umožnily nové ekonomické modely s vyššími výrobními náklady. Tvůrci tedy měli relativně svobodný prostor pro svůj umělecký projekt, což je jedním ze znaků $\mathrm{HBO}$, přinášející svým předplatitelům inovativní televizní projekty (např. The Sopranos, Odpočívej v pokoji, Špina Baltimoru). Lucy Küngová objasňuje, jak HBO staví strategii své tvorby na „jinakosti“ (KÜNG 2017: 119). Usiluje totiž o vznik seriálů, které se budou lišit od běžné produkce tím, že získají ocenění kritiků a zároveň budou komerčně úspěšné: „HBO hledá pořady, které jsou jiné a jedinečné a nepřipomínají starší seriály“ (KÜNG 2017: 119, přel. $\mathrm{PB})$. Rámec, v němž se autoři pohybují, je značně odbyrokratizovaný prostor, přičemž od filmařů se očekává kreativní prrístup a na oplátku je jim nabídnuta široká umělecká svoboda (KÜNG 2017). ${ }^{2}$ To se ostatně stalo i v tomto přípa-

1) V českém prostředí se poetikou televizního seriálu zabývá Radomír D. Kokeš, jehož kniha Světy na pokračování: rozbor možností seriálového vyprávění nabízí nástroje $\mathrm{k}$ analýze seriálové fikce.

2) HBO úspěšně rozvíjí tuto strategii i v České republice, kde nedávno vznikl kritiky oceňovaný televizní seriál Pustina. Pozitivní ohlas k tvorbě HBO vyjádřil český režisér a producent Viktor Tauš: „HBO [...] vyvíjí svoje věci ve spolupráci s producenty a režiséry. [...] HBO investuje do vývoje látek signifikantní částky a poskytuje kvalifikovanou dramaturgii. Je radost mít tady takhle silného hráče s vizí“ (SZCZEPANIK 2016: 141). 
dě. Podle slov režisérky seriálu Lisy Cholodenkové, která natočila všechny čtyři díly, byla tvưrčí práce týmu velmi svobodná a nebyla poznamenána přílišnými kompromisy: „Jako bychom točili čtyřhodinový film, jenže se strukturou, která může fungovat jen v televizi“ (COLLIN 2014, cit. 26. 6. 2017, přel. PB). Sama režisérka přizvala k natáčení kameramana Freda Elmse, s nímž se znala z jednoho z panelů festivalu nezávislých filmů Sundance. Frances McDormandová pak zase přivedla známého skladatele filmové hudby Cartera Burwella.

Součástí kreativní práce byla volba kamerových postupů, at šlo o snímání jednotlivých scén, nebo záběrů na novoanglickou krajinu (Joel Meyerowitz). Natáčení mělo být podle požadavků HBO uskutečněno digitální kamerou, nakonec však byla série snímána na $35 \mathrm{~mm}$ film. Kameraman Fred Elmes zmiňuje důvody této změny: „[...] protože se velká část příběhu odehrává v minulosti, vybraný materiál by působil trochu odlišným dojmem; patina zrnitosti by pravděpodobně trochu více podpořila dobovou povahu vyprávění“ (KAUFMAN 2014, cit. 4. 5. 2017, přel. PB). Využíváno bylo kromě komplikovanějších scén s více postaveními jediné kamery, a také steadicamu a vozíku, aby tak bylo docíleno plynulých, jednoduchých pohybů, které měly pomoci soustředit se na jednotlivé postavy (KAUFMAN 2014, cit. 4. 5. 2017). Tato a další kreativní rozhodnutí měla za cíl nalézt polohu, $\mathrm{z}$ níž lze důvěryhodně pozorovat přediva mezilidských vztahů a dramat dějících se na americkém severovýchodě 80 . let.

\section{Symbolický př́iběh v temném seriálu}

Adaptování se neslo v duchu symboličtějšího zatížení obrazu světa, než je tomu $\mathrm{v}$ předloze, a struktura děje se zhustila na to nejpodstatnější, co mohlo přispět k alegorickému podobenství. „Povídkový román“, jak bývá kniha nazývána, je rozdělen do třinácti kapitol a jeho základní rámec časově odpovídá období přibližně deseti let. Podle jedné z recenzentek knihy, Yvonne Zippové, každý z jednotlivých příběhů „slouží jako individuální mikrokosmos maloměstského života se všemi pomluvami, drobnými laskavostmi a každodenními tragédiemi“ (ZIPPOVÁ 2008, cit. 27. 6. 2017, přel. PB). Třináct kapitol zhustili adaptátoři do čtyř, které s využitím knihy nazvali Lékárna, Př́liv, Jiná cesta a Bezpečí. Tyto názvy jednotlivých dílů seriálu prohlubují symbolický potenciál předlohy, nebot’ s větším důrazem nasvěcují děje, které jsou obsaženy v románu a v dílčích kapitolách nesoucích jiný název. Právě v této hře s původní látkou je patrná vynalézavost autorů seriálu. 
Podle scenáristky Jane Andersonové HBO požaduje, aby šel natáčený příběh s dobou, ale zároveň aby něčím iritoval své publikum (SNYDER 2017). Televizní seriál Olive Kitteridgeová je v kontextu současné americké produkce pozoruhodný tím, v jak pesimistickém duchu jeho příběh ukazuje vyprázdněnost lidského konání a neuspokojivou situaci liberální společnosti. $V$ jedné z recenzí se o něm trefně píše jako o „nejúžasněji tragickém seriálu v televizi po dlouhou dobu [...]“ (JONES 2014, cit. 27. 6. 2017, přel. PB). Jednoduchou představu o spořádané společnosti narušuje hlavní postava vyprávění, stárnoucí Olive Kitteridgeová. V knižní podobě zaujímala $\mathrm{v}$ některých $\mathrm{z}$ vykreslených příběhů ústřední místo, v jiných se objevovala jen okrajově, mihla se se svým manželem v popisovaných situacích, nebo byla zmíněna $v$ konverzacích dalších postav. $V$ seriálu se tento komplikovaný jedinec dostává ještě více do popředí. Olive je žena, jejíž motivace není zcela snadné pochopit. Komunitě, v níž žije, se jeví jako rozporuplná postava: obávaná učitelka matematiky na místní střední škole, popudlivá, svéhlavá, zároveň je však soucítící s těžkými osudy jiných lidí. Její charakter trefně vystihla Yvonne Zippová, která v ní vidí „nedůtklivou protagonistku s jemným srdcem“ (ZIPPOVÁ 2008, cit. 27. 6. 2017, přel. PB). Svým jednáním se pokouší vymanit z předepsaných společenských rolí; svou výstředností (například až chorobnou závislostí na jídle, obzvláště koblihách) odhaluje předsudky, s nimiž se lidé navzájem posuzují. Olive obhajuje svoji identitu uprostřed mezilidského míjení a konfliktů každodenního života. Sled událostí majících dopad na její život přitom není nikterak veselý: její otec spáchal sebevraždu, kolega-učitel, $\mathrm{k}$ němuž pocitovala milostné emoce, zemřel při autonehodě, syn Christopher se oženil s nepřívětivou, panovačnou ženou, opustil rodiče a posléze se rozvedl, manžel Henry zůstal paralyzován po mrtvici a po několika letech zemřel.

To vše se děje v kontextu rozpadu tradiční společenské struktury a rozmáhající se deziluze. Obzvláště literárnímu vyprávění dominuje motiv frustrace lidí $\mathrm{z}$ toho, že nežijí v bohatém americkém městě, nýbrž v odlehlém kraji Nové Anglie - Maine - lesnaté oblasti s malými pobřežními městečky. Podle Louisy Thomesové se děj odehrává $\mathrm{v}$ „typicky novoanglickém městečku, kde lidé servírují pečené fazole a kečup, když přijde návštěva, a mluví se známými dolnovýchodním nářečím ('ay-yuh')“ (THOMAS 2008, cit. 27. 6. 2017, přel. PB). Olive do tohoto provinčního prostředí patří, společně s ostatními lidmi jej utváří a je současně jeho produktem. Adaptátoři tuto souhru prostředí a lidských životů četli obdobně a hledali vhodné místo vystihující specifické rysy pobřežního městečka. Natáčení probíhalo v Gloucesteru, Rockportu a Essexu, které měly svým charakterem lépe vyjádřit změnu, $\mathrm{k}$ níž v posledním čtvrtstoletí došlo - 
- $\mathrm{z}$ dělnického městečka s malými firmami se stalo místo, $\mathrm{v}$ němž se byznys řídí nároky velkých korporací (OWEN 2014, cit. 27. 6. 2017).

Kniha i seriál spojují úlomky každodenních situací v neveselý obraz. Viníkem civilizační krize je podle Frances McDormandové typ moderní mentality postavené na pokroku, který přináší ztrátu jistot a solidarity: „Domnívám se, že postindustriální Ameriku omámil pokrok. Každého někdy v životě přepadne určitá kulturní malátnost“" (HBO 2014, cit. 27. 6. 2017, přel. PB). V tomto ohledu se naplňují slova Catherine Johnsonové, podle níž je jedním z charakteristických znaků quality TVi: „,...] zkoumání současných typů neklidu souvisejících s pozdním kapitalismem" (JOHNSON 2005: 61, přel. PB). Spisovatelka a scenáristka ovšem nezůstaly jen u angažovaného, sociálně kritického pohledu. Šly dál a oblast Maine zalidnily zvláštními typy postav zakoušejícími depresivní pocity osamocení. Rozpad společenských vazeb v rodině či komunitě se tudíž děje na úrovni psychologie, a v takovém případě nelze najít jednoduché sociální řešení, jež by situaci zlepšilo. Postavy utrmácené skepsí a deziluzí, nesoucí si s sebou svá traumata, volí mezi sebedestrukcí a - ojediněle - opětovným nalezením důvěry k životu. Skepse, deziluze a trauma už zde tedy nejsou něčím vnějškovým, ale jsou natolik internalizovány, že se vytrácí ponětí o jejich patologičnosti a naopak jsou téměř normalizovány - což je patrné z jejich kvantitativního výskytu v televizním seriálu. Obzvláště ve druhé epizodě Olive Kitteridgeové se zdá, jako by jediná skutečná identita byla patologická a žádná normalita neexistovala.

Tato neveselá perspektiva je ostatně navozena od úvodní připsané scény, v níž se Olive chystá spáchat sebevraždu. Scenáristka jistě hledala způsob, jak hned od začátku uchopit pozornost diváků a přitáhnout je do děje narůstajícím napětím. Touto novou scénou ovšem zároveň osvětlila vyznění celého příběhu: člověk je vržen do světa a vydán napospas samotě a odcizení. Takový vstup do fikčního světa je velmi odlišný od románu, nebot’ ten začíná vyprávěním o Henrym - manželovi Olive - a jeho cestách do své lékárny ve městě. Henry je ztělesněním mírnosti a křehkosti. Každý den nasedá do svého automobilu a míři do lékárny, jejíž pečlivé uspořádání mu přináší klid. Zde zapomíná na svoje manželské problémy či nejistoty s výchovou syna. $Z$ prvního odstavce knihy vyznívá mužův vztah k přírodě, vnímání ubíhající krajiny, v níž se ve všech ročních obdobích snoubí kontrast pevniny a oceánu: „Skoro vždycky jel s částečně staženým okénkem, protože miloval vůni borovic a těžkého slaného vzduchu“ (STROUT 2010: 7). Takový vstup do vyprávění je smírlivější než moment, kdy si člověk uvědomuje meze vlastního života a reaguje na ně obzvláště tímto radikálně negativním krokem. I v prvním dílu seriálu sehraje Henry svůj důležitý 

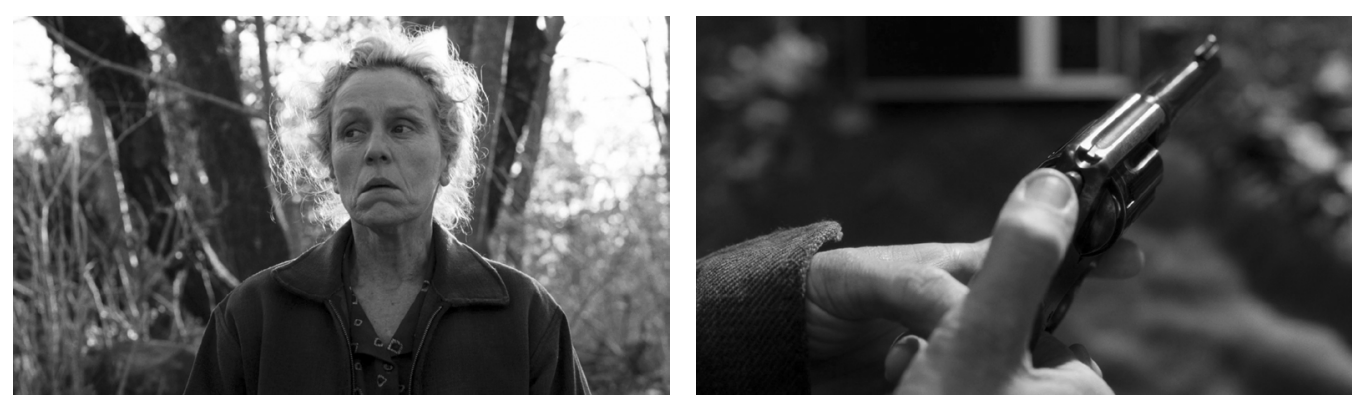

Olive Kitteridgeová se chystá spáchat sebevraždu. Olive Kitteridgeová (2014, HBO)

part, předtím však spatříme Olive chystající se zastřelit sama sebe. Vidíme její nohy, které pomalu kráčejí spadaným listím, a slyšíme zpěv ptáků. Šouravý krok i taška nesená těsně nad zemí naznačují vyčerpání. Žena je součástí velkého přírodního celku - jako by vrostla do lesa. Tam, kde končí civilizace a začíná pustina, je člověk vystaven nebezpečí a ztrácí kontrolu nad sebou samým. Kamera postupně ukazuje ženu v nenápadném, hnědém oděvu, která našla příhodné místo pro odchod ze světa. Jejími bílými vlasy prosvítá pozdní slunce. Namísto zbraně však nejprve vytahuje deku, kterou rozprostře na zem, odhodí na ni dopis na rozloučenou a klíče, a nakonec vytáhne tranzistorové rádio a naladí je na stanici s klasickou hudbou. Teprve posléze vybaluje revolver a vkládá do něj náboj. Zhluboka se nadechuje a pohlédne přitom směrem vzhůru. Následuje působivá kombinace záběrů na bezlisté větve snímané proti modré obloze, jimiž prochvívá vítr. Na jednom ze záběrů vidíme opuštěné hnízdo, což odkazuje k nejhlubšímu zklamání této ženy: zůstala úplně sama v prázdném domě. S natažením kohoutku zbraně a vydechnutím scéna končí a diváci mohou domýšlet, zda černá obrazovka znamená konec Olivina života.

\section{Rebelka s pozitivními přesahy}

Společnost nežije zcela autenticky a je modelována různými kulturními artefakty, tedy i televizními seriály. Olive Kitteridgeová narušuje horizont očekávání diváků, nebot se vzpírá nejrozšířenější indoktrinaci stereotypů chování, které nám televizní vysílání mnohdy předkládá: máme být vstřícní, milí, veselí, komunikativní, neironičtí. Hlavní postava Olive tuto představu nijak nenaplňuje, není laskavá ani konformní. Je komplikovaným jedincem opakovaně porušujícím základní 
pravidla slušného chování. Dokáže být zlomyslná až potouchlá. Rázně napadá jazykové manipulace, které mají alespoň vnějškově udržet měštácký klid. Je nevlídná ke svému muži, vyhazuje do koše jeho valentýnské přání, a když se Henry ve slabé chvíli ujištuje, zda jej nikdy neopustí, odvětí: „Propána, Henry, z tebe by se ženské udělalo nanic“" (STROUT 2010: 34). Je nespolečenská a nezdvořilá. Takové rozvržení této postavy odpovídá postupům typickým pro seriály quality $T V$, které do centra vyprávění staví „vysoce nepřijemné lidi“, které označuje za antihrdiny. Převažují postavy mužské, a když už se objeví postava ženská, pak bývají „bud’ soucitné, ale pichlavé, jako Veronica Marsová, Starbuck v Battlestar Galactica a Sarah v Zločinu, nebo se jedná o komedičtější přístupy k morálně ambivalentním ženám jako v seriálech Sex ve městě, Tráva, Sestřička Jackie a Mé novéjá" (MITTEL 2015: 150, přel. PB). Její nepoplatnost konvencím je demonstrována v křiklavém kontrastu ke společenské falši ztotožněné postavami matky a otce první synovy manželky. Tento pár se sice objeví v seriálu jen ve druhém dílu, kdy si po krátké známosti bere syn Kitteridgeových Christopher ambiciózní lékařku, i to však stačí k vytvoření silně kontrapunktické situace. Vzdálenost hodnotových světů obou manželských párů je dána kulturně i geograficky, nebot Kitteridgeovi žijí na často nevlídném severovýchodním pobřeží, zatímco rodiče dívky ve slunné Kalifornii. Ač se Kitteridgeovým vede dobře - postavili dům sobě i svému synovi a zabezpečili se na důchod -, nejsou nijak spojováni s blahobytem a konzumem, jemuž se druhá

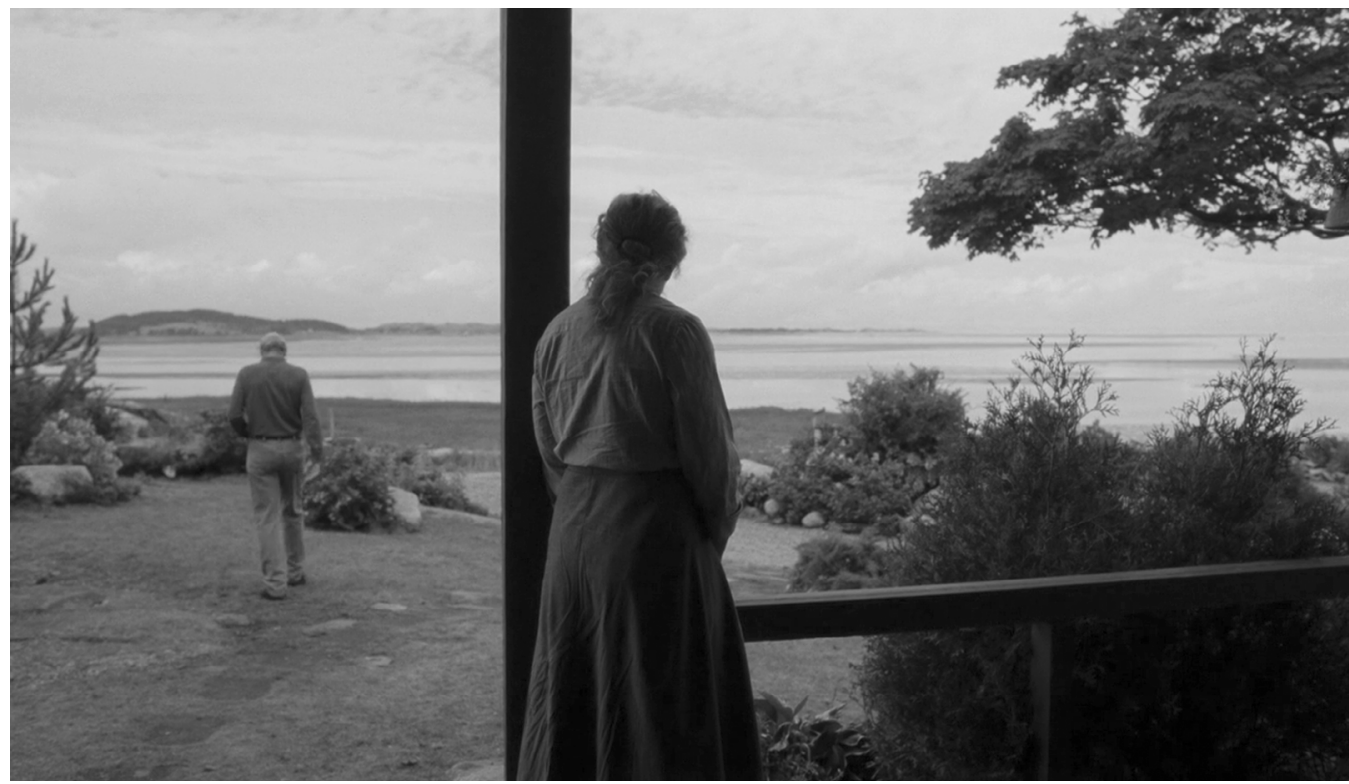

Olive a Henry žijí v domě na pobřeží oceánu. Olive Kitteridgeová (2014, HBO) 
rodina zjevně podřizuje. Henry při setkáních s rodiči dívky navozuje smířlivější tón, nebot chce za každou cenu lidi spojovat. Naprostým opakem je Olive, která prohlédla budoucí synovu ženu i tchýni a vadí jí jejich sebestředné chování a hraná přátelskost. Střetem protikladů (vyprávění kupříkladu věnuje pozornost tomu, jak si Olive sama radostně šije šaty s květinovým vzorem, které se posléze stanou terčem pomluv mezi svatebčany) je rozvíjena kritická bilance falešného světa snadné dosažitelnosti, nadbytku, prázdných gest, vysokých ambicí a neustálého soupeření. Vše vrcholí ve chvíli, kdy Olive slyší, jak o ní a o domě, který s Henrym postavili svému synovi, ve skutečnosti smýšlí její nová snacha. Reakce stárnoucí ženy je neobyčejně potouchlá: odnese jí botu a náušnice a počmárá oblečení fixou.

Louisa Thomasová si ve své recenzi knihy povšimla, že Olive: „[...] je schopná neuvěřitelné empatie, ale jedná se o nepřecitlivělou empatii“ (THOMAS 2008, cit. 4. 5. 2017, přel. PB). Tento povahový rys hlavní postavy se v jejím výkladu ukazuje ve chvíli, kdy se Olive náhodně setkává s umírající anorektickou dívku a rozpláče se nad jejím osudem: „Nevím, kdo jste, mladá dámo, ale lámete mi srdce“ (STROUT 2010: 102). Adaptace s touto románovou scénou přímo nepracuje, nicméně duchaplná lidskost je rozvinuta ve druhém dílu, kdy se Olive náhodně setkává se svým bývalým studentem Kevinem Coulsonem. Osudy tohoto mladého muže nebyly snadné. Spolužáky (včetně dospívajícího Christophera) byl ostrakizován, nebot’ si jej nedokázali zasadit do jednoznačné role. Vyrůstal jen s matkou Ráchel, která po dlouhotrvajících psychických problémech spáchala sebevraždu. Kevin se chce také zabít, a vrací se proto z New Yorku do Maine. Komplexnější obraz situace je v knižní předloze vykreslen v několika perspektivách a hlasech. $V$ prvé řadě je to pohled neštastného Kevina, občas zamlžený schizofrenními představami. Vypravěčův a Kevinův part doplňují vzpomínky na setkání s doktorem Goldsteinem, zřejmě psychologem či psychiatrem, jehož hlas vstupuje do vyprávění v podobě Kevinových vzpomínek na jeho slova: „Povahové rysy se nemění, stavy mysli ano [...]“ (STROUT 2010: 38). Pak je tu pohled Kevinovy bývalé spolužačky ze střední školy, Patty Howeové, která ve stejnou chvíli pracuje $v$ nedalekém domě a v mladém muži až přiliš dlouho sedícím ve svém autě poznává zvláštního chlapce $z$ dětství.

Televizní adaptace také uvádí diváky do kontextu, avšak jiným způsobem. Druhý díl začíná záběrem na Kevinovu matku zahánějící koštětem neexistující útočníky. Střihem se přesouváme do narativní přítomnosti a pohledem již staršího Kevina sledujeme př́istav, v němž jakýsi chlapec stejnými slovy zahání racky. Atmosféra scény vyvolává úzkost, nenadálé zvuky, ztemnělé světlo či vzpomínky na matku přinášejí dojem domnělého či reálného nebezpečí. Adaptace 
se ovšem koncentruje na detail, rozhovor mezi Kevinem a Olive. Žena narušuje intimní prostor mladíka, vtrhne do auta a bez okolků se usadí vedle něj. Brzy si povšimne pušky na zadním sedadle auta zakryté dekou a pochopí, proč se vrátil do Maine. Záhy poté začíná sama hovořit o sebevraždě svého otce a psychických problémech, které sužují celou její rodinu. Rozmlouvá s Kevinem, jako by chtěla zachytit poslední tenká vlákna, která jej drží mezi živými, obrátit jeho pozornost od zoufalství, do něhož upadl po ukončení vztahu se zvláštní dívkou, ujistit jej o vlastní identitě a ukázat mu, že nemusí následovat cestu, kterou zvolila jeho matka. To, co sama netuší, je prolnutí šílenosti do normálního života: v Kevinově psychicky narušeném pohledu se mění v ženu se sloní hlavou, která poklidně pojídá ořišky. A stejně tak netuší, že Kevin na útesu vidí modré hady obklopující Patty, která právě vyšla z domu.

Vyprávění ústí v dramatický konec, nebot’ Patty spadne do oceánu. Přežije jen proto, že si nehody všimne Olive a vyburcuje Kevina, který ji vytáhne z vody. Po záchraně tonoucí dívky pak odjíždí Kevin ke Kitteridgeům a zamíři s nimi na večeři coby společenskou přípravu na svatbu syna Christophera. Brzy je zřejmé, že se oba komplikovaní protagonisté, Olive a Kevin, do společnosti nehodí. Christoper se pokouší hovořit s Kevinem, představit mu svoji sebestřednou snoubenku, z jejich rozhovoru je nicméně patrné, že jen obtížně hledají společná témata. V jednu chvíli Kevin utne prázdnou debatu a vzdálí se od společnosti. Pozornost vyprávění se však neobrací k „normálním“ svatebčanům, nýbrž zůstává s Kevinem, který se zaposlouchá do hudby klavíristky a všimne si, že za barovým pultem visí lístek s jakýmsi záznamem. Je to úryvek z básně Johna Berrymana, který zde před mnoha lety napsal jeho učitel angličtiny Jim O'Casy těsně před tím, než se zabil při autonehodě. Spojitost zde není náhodná, nebot právě díky platonickému vztahu k tomuto nonkonformnímu muži mohla
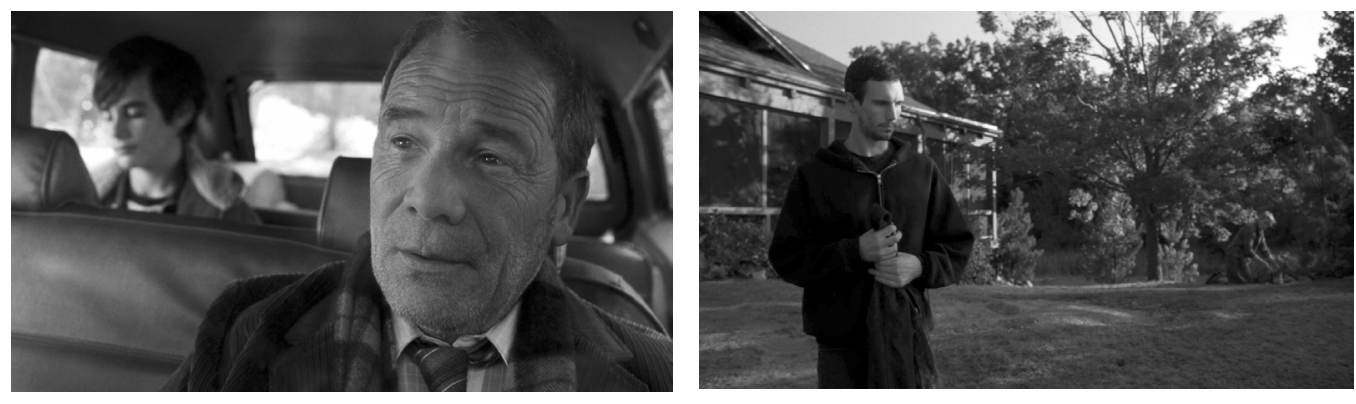

Prvnímu záběru dominuje nonkonformní učitel Jim O’Casey, který udílí Kevinovi rady do života. Na druhém Kevin odchází od Kitteridgeů, zatímco Olive v pozadí pracuje na zahradě.

Olive Kitteridgeová (2014, HBO) 
Olive alespoň na chvíli uniknout ze svazujícího světa konvencí. V následujícím flashbacku se vracíme do Kevinova dětství a sledujeme, jak učitel Jim odváží Kevina za jeho nemocnou matkou. Skok v čase je vyjádřen i kontrastní změnou hudebního žánru. Zatímco klavíristka v baru zpívala známý hit hudebního dua Carpenters - Close To You, který v její interpretaci odpovídá intimní atmosféře, rozezní se naplno protestní píseň Boba Dylana On the Road Again. Opět se ocitáme v uzavřeném prostoru automobilu, kde zůstal jen Jim O'Casy a Kevin. Učitel se ptá chlapce na jeho rodinou situaci a nabádá jej, aby všemu vzdoroval: „Kašli na autority. Plnou parou vpřed“ (Olive Kitteridgeová 2014). Zvláštní a komplikovaní jedinci, Olive, Jim, Kevin, vytvářejí protiváhu prázdným společenským gestům a jako jedni z mála mohou dospět k autentické zkušenosti.

\section{Pilulky na trápení}

Televiznímu seriálu Olive Kitteridgová dominuje přítomnost doktorů a léků. Jak se nicméně ukáže, možnosti medicíny jsou omezené a nedochází k úplnému uzdravení jedince či komunity. Nabízí se tedy otázka, jaký je zde důvod pro tak dominantní tematizaci lékařské profese. Jde o způsob sociální kontroly? Má snad být s pomocí valia či prozaku udržována pohromadě zdánlivě funkční společnost? Tento rozpor se v prvé řadě dotýká Henryho, který sám svědomitě každý den připravuje a vydává léky. Hned na začátku prvního dílu jsme svědky situace, kdy odmítá vydat valium Kevinově matce Ráchel. Henry je pečlivý, snadno poznává, že žena získala nový recept u jiného lékaře a pokouší se tak zvýšit dávku léků. Ráchel zoufale obchází systém kontroly, nebot’ - podobně jako dalším postavám - jí předepsaná léčba nezabírá. Vykreslena přitom není negativně, spíše naopak, obzvláště Olive ji vnímá jako bystrou ženu. Záhy poté na ulici zkolabuje Henryho asistentka a lékárník se ji snaží marně oživit. A je to právě Ráchel, která stojí nad bezvládným tělem a Henrymu říká, že je asistentka mrtvá. Vyměňují si role, ona sama poznává stav věcí a dokáže je pojmenovat tak, jak jsou.

Také Henry hledá lék sám pro sebe, nebot jeho soukromý život nepůsobí utěšeným dojmem a soukromí je vykresleno jako série konfliktů s manželkou a s dospívajícím synem. Tyto napjaté rodinné situace ukazují jeho narůstající pocit osamění. Útěchu nachází u Denise, mladičké asistentky v lékárně. Naivní 
dívka, kterou Olive nelichotivě nazývá myškou, je karikaturou všech dobrých vlastností, čímž vytváří zřetelný kontrast k Olive. Je milá, veselá, radostně přitakává prostému rodinnému štěstí. Do Henryho života vnáší bezprostřední radost. Idylická situace je však narušena nečekanou událostí: manžel Denise je neštastnou náhodou zraněn na lovu a Henry jen bezmocně přihližź jeho smrti. Henry se pak snaží dívce pomoci různými způsoby, ale všechny tyto pokusy jsou marné a svým absurdním vyzněním nahrávají ironickým komentářům Olive (když Henry koupí dívce malé kotátko, je velmi štastná, sama si je však náhodou přejede automobilem). Ani závěrečné vyústění této dějové linky není povzbudivé, nebot' i s přičiněním Henryho se dívka znovu vdá, tentokrát za pomocníka z lékárny; naplní se tím sice její touha po rodině, ale ve svazku s chamtivým a pragmaticky uvažujícím mužem není štastná. Její sny ve společnosti blahobytu, karikované fotografiemi obtloustlého potomka skákajícího do nově vybudovaného bazénu za domem, jsou neuskutečnitelné.

V této tematice však hraje zásadní roli epizoda ze třetího dílu. Henry a Olive si na společné večeři vyměňují s přáteli svá zklamání z nefunkčních rodinných vazeb. Kitteridgeovi zakoušejí hořkost z nenadálého odjezdu syna Christophera $z$ Maine do Kalifornie, práátelé zase $z$ toho, jak se k nim chová jejich dcera a vnuci. Při návratu domů Olive vyzývá Henryho, aby ji okamžitě přivezl na nějaké místo s toaletou. Náhodou přijíždí k nemocnici, kde je Olive vyzvána sestrou a lékařem, aby se podrobila vyšetření, nebot’ předešlého večera zde za podobných okolností zemřela starší žena. Olive sice namítá, že je zdravá, ale nakonec kapituluje a připravuje se na vyšetření. Namísto lékaře však do ordinace vtrhnou ozbrojení zloději, kteři ji odvedou ke spoutanému Henrymu a zdravotnímu personálu. Olive a Henry jednají v této traumatizující situaci nepatřičně, Henry vyzývá ozbrojeného muže, aby mluvil slušně, Olive mu zase radí, jak by měl léčit své akné. Před příjezdem policie, ve chvíli, kdy se domnívají, že budou zabiti, dojde mezi oběma manžely ke konfliktu. Svázáni na podlaze si vyčítají různé křivdy, především špatný vliv na syna, který je opustil, rozvedl se a nenaplnil jejich generací obecně přijímanou představu rodinného života. Scéna je místy až naturalistická, nevyhýbá se zdůraznění nepředvídatelnosti některých událostí tím, že kamera v detailu ukáže Henryho pomočené kalhoty. Oba manželé jsou sice v centru lékařské profese, její bezmoc je ale zřetelná - lékař i sestra jsou svázáni na zemi, zatímco pány nad životem a smrtí se stali dva narkomani s maskami na obličejích. Přece však vyjde najevo, jak Olive a Henryho souží problematické vztahy, z nichž mohou pramenit jejich zdravotní problémy. 
Henry je nakonec poté, co celý život s laskavostí pomáhal jiným, stižen nenadálou mrtvicí a několik let dožívá v domě s pečovatelskou službou. Zatímco jeho syn je bezmocným pozorovatelem nevratné proměny vlastního otce, Olive svého manžela stále navštěvuje, hovoří s ním, vypráví mu příběhy z městečka. Odmítá se smířit s tím, co jí vnucuje její okolí, včetně syna: dokud je Henry naži(1) vu, hovoří s ním, přivádí na návštěvu jejich psa, přináší mu květiny. Tyto scény naplňují komentár̆, který divák dostával prostřednictvím opakujících se symbolických sdělení v úvodních titulcích filmu. V nich opakovaně spatřuje spojování protikladů (hořkého a sladkého), připomínky pomíjivosti (kostky ledu tající ve whisky, cukr snášející se na koblihy připomínající sníh), spění ke konci (poloprázdný balíček cigaret) a jeden z nejtypičtějších symbolů lidského života - lod'ku na rozbouřeném moři. Marnost světa se potvrzuje pádem Henryho do stavu mezi životem a smrtí, avšak počínání Olive demonstruje, že člověk má možnost této marnosti vzdorovat a otevřít se plné existenci.

\section{Zvláštní „happy end“}

Televizní seriál končí zvláštním „happy endem“: Olive se po nezdařeném setkání se synem, který nyní čeká dítě s novou ženou, ocitá v naprosté samotě. $Z$ té je vytržena nenadálým setkáním s nedávno ovdovělým Jackem Kennisonem. Jejich sbližování však končí konfliktem a Olive se rozhodne pro sebevraždu. $Z$ té je vyrušena malými dětmi, které se domnívají, že je na pikniku, a vyzvou ji, aby po sobě nezanechala nepořádek. Tento nenadálý zásah připomíná situaci, kdy sama nečekaně vstoupila do Kevinova života a společně s dalšími okolnostmi přispěla $\mathrm{k}$ tomu, že nedokonal svůj sebevražedný úmysl. Tragické vyústění naznačené $\mathrm{v}$ úvodu nebylo naplněno a životní krize naopak přispěla $\mathrm{k}$ sebeobnově Olive: vrací se k Jackovi a pojmenovává své chyby, když přiznává, že její vztah k manželu i synovi byl narušen sérií nedorozumění, na nichž měla svůj podíl. Po všech ztrátách nachází své místo ve světě, který se jí po odcizení se synem zdál být bezútěšný. V závěrečné scéně leží dva zestárnuvší lidé v posteli, zakoušejí úzkost ze života bez svých partnerů, z neschopnosti hovořit se svými dětmi i z vlastní smrti (Jack se ptá Olive, zda mu ještě bije srdce). Olive se zadívá z okna Jackova pokoje na mořskou hladinu, která se ztišila. Zdá se, že se Olive smířila s významově ambivalentní povahou lidského života: „Tento svět 


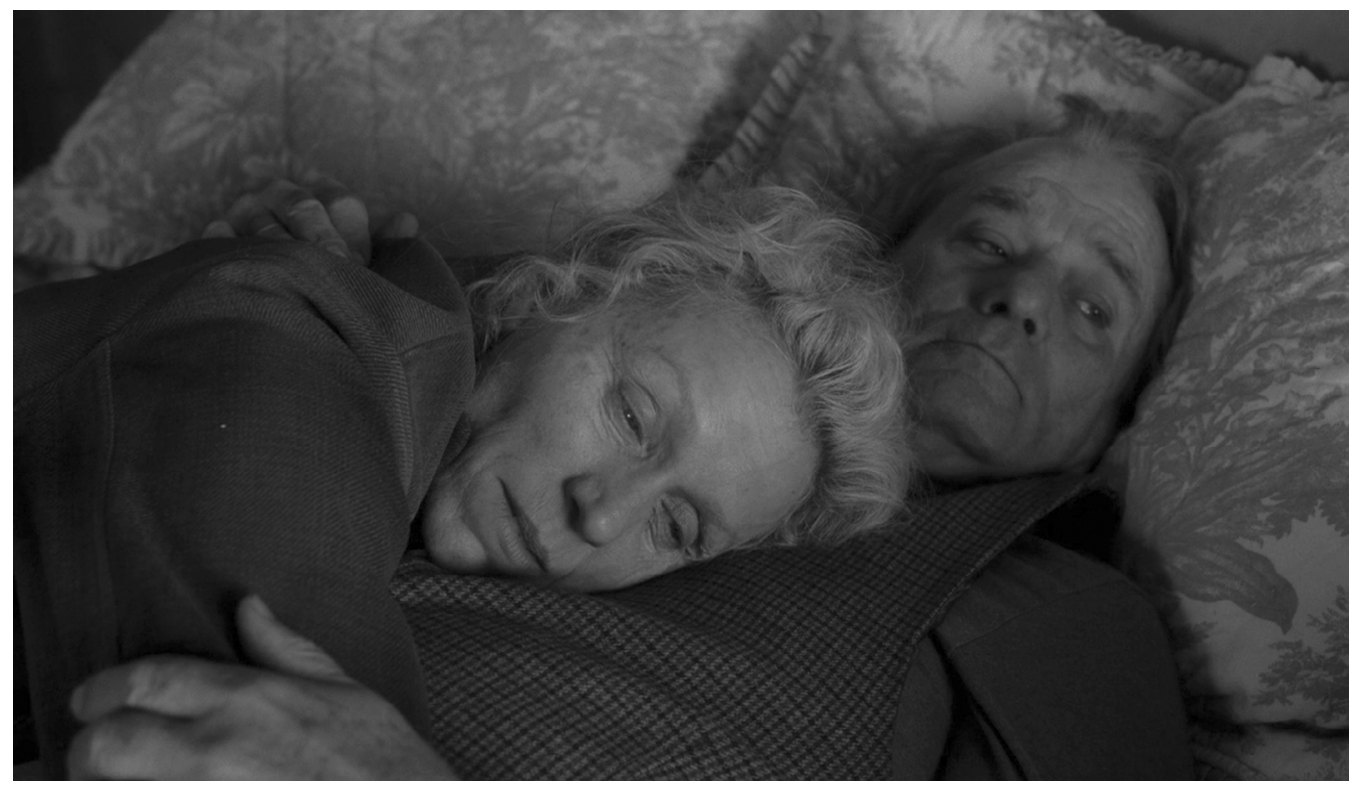

Olive s Jackem Kennisonem v závěru seriálu. Olive Kitteridgeová (2014, HBO)

mě mate. Ještě jej nechci opustit" (Olive Kitteridgeová 2014). Prostřednictvím této zvláštní postavy, rebelky s pozitivními přesahy, dospíváme $\mathrm{k}$ významově otevřenému konci. Svět je pomíjivý a s ním i veškeré lidské snažení, přece však je v něm po očistné cestě sebepoznání možné najít bezpečné místo, z něhož se člověku jeví být snesitelným.

Nedokončenou sebevraždou adaptace odkryla svou základní existenciální situaci, a to, zda lze nalézt a potvrdit smysl „opravdového života“. Blízkost mezi lidmi tkví jen v tom, že jsou všichni stejně odsouzeni k životu, ale každý se s tím vypořádává jiným zpo̊sobem. Kevin, který nakonec sebevraždu nespáchal, bez rozloučení opouští dům Olive a Henryho a vrací se na místo, kde zachránil tonoucí dívku. Spatříme jej, jak hledí do vln a v následujícím flashbacku se vracíme k dramatickému boji o holý život. Dva mladí lidé vzdorují oceánu ztělesňujícímu prvotní chaos, bojují o holý život. Záběry na Patty ukazují, jak ji víry stahují ke dnu a ona se marně snaží chytit něčeho pevného. Vidíme lidské ruce, které se nakonec setkají, Kevin dívku chytí a vytáhne ji na břeh. V následujícím záběru z narativní př́tomnosti vidíme Kevinův obraz v okně, za nímž Patty chystá snídani. Za oknem je tabulka se zřetelně čitelným textem: „Omlouváme se. Máme zavřeno“, avšak v takové situaci běžné konvence padají a dívka zve Kevina dovnitř. Hovoří spolu o prožitém traumatu, ukazují si své šrámy na těle způsobené ostrými 
kameny. Kevin nemůže zůstat jen u bolestí těla, potřebuje jít dál a dívky se ptá, zda skočila do vody úmyslně. Dozvídá se, že spadla náhodou, když trhala květiny. Zaražený Kevin je překvapen, že obyčejné květiny mohou člověku přinést útěchu a rozpláče se. Každý se nakonec musí sám vypořádat se svou existencí jiným způsobem, at' už jsou to květiny, nebo zbraň. Zkušenost je nepřenositelná, každý žije jiný život a vše si musí protrpět. Alespoň však může člověk potkat člověka, být překvapen jeho solidaritou, pozitivním jednáním, jímž vzdorujeme chaosu a absurditě. Tímto dovršením kruhu vzájemné pomoci (v knižní podobě neobsaženým) je naznačeno možné východisko pro současný odlidštěný svět, v němž dominuje nepochopení a samota. Ve scéně v moři, majícím zde symbolickou platnost, kdy v zápase o život druhého má pomocná ruka rovněž fatální význam, je pointa seriálu potvrzena.

\section{Závěr}

Adaptace dnes často vykládáme jako palimpsesty, jimiž prosvítá množství různých vlivů (HUTCHEON 2013: 33). Seriál Olive Kitteridgeová nevede dialog jen s literární fikcí, jejíž příběhy a postavy přenesli adaptátoři do nového média, ale především interpretuje román prizmatem quality $T V$. Kniha adaptátorům poskytla zdroj v podobě látek a hodnot souznících s „temnější kvalitou“ obsahů reflektujících proměny americké společnosti. Jestliže se temnější nálady staly základním znakem kvality v současné americké kultuře, což je zásadně odlišuje od neúnavné optimistické povahy mainstreamových produktů, pak se Olive Kitteridgeová této nové normy nejen drží, ale ještě ji dále posouvá. Programovému optimismu nastavuje zrcadlo a útočí na jeho vyprázdněnost. Zároveň se od soudobé produkce odlišuje, nebot se pod pláštěm temné nálady nepokouší ospravedlnit zobrazení sexu a násilí, což jsou dva tradiční elementy, které pohánějí reakce diváků. Vedle toho Olive Kitteridgeová užívá postupů typických pro uměleckou kinematografii, narušuje hranice žánrů, zalidňuje fikční svět morálně rozpolcenými postavami, odkrývá otázky ekonomického a politického úpadku.

Autor děkuje Miroslavu Kotáskovi a Petru Vokř́nkovi za debatu k tomuto tématu. 


\section{TELEVIZNí SERIÁLY}

BATTLESTAR GALACTICA 2004 (BSkyB)

FARGO 2014 (Fargo, FX Productions)

MÉ NOVÉ JÁ 2011 (Enlightened, Rip Cord Productions)

MĚSTEČKO TWIN PEAKS 1990 (Twin Peaks, ABC)

ODPOČÍVEJ V POKOJI 2001 (Six Feet Under, HBO)

OLIVE KITTERIDGEOVÁ 2014 (Olive Kitteridge, HBO)

PUSTINA 2016 (Wasteland, HBO)

SESTŘIČKA JACKIE 2009 (Nurse Jackie, Showtime Networks)

SEX VE MĚSTË 1998 (Sex and the City, HBO)

ŠPÍNA BALTIMORU 2002 (The Wire, HBO)

TEMNÝ PŘIPAD 2014 (True Detective, HBO)

THE MISSING 2014 (BBC)

THE SOPRANOS 2014 (HBO)

TRÁVA 2005 (WEEDS, Lions Gate Television)

VERONICA MARS 2014 (Warner Bros. Digital Distribution)

ZLOČIN 2011 (The Killing, KMF Films)

\section{LITERATURA}

\section{BROWN, Simon}

2010 „Cult Channels: Showtime, FX, and Cult TV“ in Stacey Abbott (Hg.): The Cult TV Book (London: I. B. Tauris), s. 155-162

COLLIN, Robbie

2014 „Olive Kitteridge, review: 'brilliant”, Telegraph.co.uk; dostupné z: <http://www.telegraph.co.uk/culture/ tvandradio/tv-and-radio-reviews/11063489/Olive-Kitteridge-review-brilliant.html>, př́stup 27. 6. 2017 $\mathrm{HBO}$

2014 „03: A Different Road“, Hbo.com; dostupné z: <http://www.hbo.com/olive-kitteridge/episodes/01/03a-different-road/interview/frances-mcdormand.html>, př́stup 27. 6. 2017

HUTCHEON, Linda

2013 A Theory of Adaptation (London and New York: Routledge)

JOHNSON, Catherine

2005 „Quality/Cult Television: The X-Files and Television History“, in Michael Hammond and Lucy Mazdon (eds): The Contemporary Television Series (Edinburgh: Edinburgh University Press), s. 57-71

JONES, Ellen E.

2014 „Olive Kitteridge, Sky Atlantic - TV review: The most magnificently miserable show on television in a long time“, Independent.co.uk; dostupné z: <http://www.independent.co.uk/arts-entertainment/tv/ reviews/olive-kitteridge-sky-atlantic-review-the-most-magnificently-miserable-show-on-television-in-along-9923641.html>, př́stup 27. 6. 2016 
Petr Bubeníček

Jiná podoba př́iběhu o osamělosti v televizním seriálu Olive Kitteridgeová

\section{KAUFMAN, Debra}

2014 „Love and Loss: The Interwoven Narrative of 'Olive Kitteridge'“; Creativeplanetnetwork.com; dostupné z: <http://www.creativeplanetnetwork.com/news/shoot/love-and-loss-interwoven-narrative-olive-kitteridge/607350>, př́stup 4. 5. 2017

KOKEŠ, Radomír D.

2016 Světy na pokračování: rozbor možností seriálového vyprávění (Praha: Akropolis)

KÜNG, Lucy

2017 Strategic Management in the Meadia. Theory to Practice (London: Sage), s. 19

O'SULLIVAN, Sean

2017 „Broken on Purpose: Poetry, Serial Television, and the Season“, in J. Rivkin a M. Ryan: Literary Theory: an anthology (Hoboken: John Wiley \& Sons). Dostupné z: <https://books.google.cz/boo $\mathrm{ks}$ ?id=XIL5DQAAQBAJ\&pg=PT149\&dq=the+new+TV+series+O\%27Sullivan\&hl=cs\&sa=X\&redir esc=y\# $\mathrm{v}=$ onepage\&q=the\%20new\%20TV\%20series\%200'Sullivan\&f=false >, prŕstup 4. 5. 2017

McCABE, Janet - AKASS, Kim

2007 Quality TV: Contemporary American Television and Beyond (London and New York: I.B.Tauris)

MITTEL, Jason

2015 Complex TV: The Poetics of Contemporary Television Storytelling (New York: New York University Press)

\section{OWEN, Rob}

2014 „Tuned In: Attention to detail helps 'Olive Kitteridge““, Post-gazette.com; dostupné z: <http://www. post-gazette.com/ae/tv-radio/2014/10/31/Tuned-In-Attention-to-detail-helps-Olive-Kitteridge/stories/201410290179>, př́stup 27. 6. 2017

\section{SOLLOSI, Mary}

2014 „Top Screenwriters Reveal How To Avoid the Pitfalls of Film Adaptation“, Filmindependent.org; Dostupné z: <https://www.filmindependent.org/blog/top-screenwriters-reveal-how-to-avoid-the-pitfallsof-film-adaptation/>, př́stup 27. 6. 2017

SNYDER, Mary H.

2017 „Adaptation in Theory and Practice. Mending the Imaginary Fence“, in T. Leitch (ed.): The Oxford Handbook of Adaptation Studies (New York: Oxford University Press), s. 101-115

STROUT, Elizabeth

2010 Olive Kitteridgeová (Brno: Jota)

SZCZEPANIK, Petr

2016 „Najít si svou skupinu diváků na co nejvíce místech světa“, Iluminace, roč. 28, č. 1, s. 129-148; dostupné z <http://www.iluminace.cz/images/obsah/rozhovor_taus_1_2016.pdf〉, přístup: 12. 7. 2017 


\section{TOMPSON, Robert J.}

1996 Television's second golden age: From Hill Street Blues to ER (New York: Continuum)

\section{THOMAS, Luisa}

2008 „The Locals“, Nytimes.com; dostupné z: <http://www.nytimes.com/2008/04/20/books/review/ Thomas-t.html>, př́stup 4. 5. 2017

THOMPSON, Kristin

2003 Storytelling in Film and Television (Cambridge: Harvard University Press)

\section{ZIPP, Yvonne}

2008 „A prickly protagonist with a tender heart“, Csmonitor.com; dostupné z: <https://www.csmonitor. com/Books/Book-Reviews/2008/0516/a-prickly-protagonist-with-a-tender-heart>, př́stup 27. 6. 2017

Mgr. Petr Bubeníček, Ph.D., petrb@phil.muni.cz, Ústav české literatury a knihovnictví, Filozofická fakulta, Masarykova univerzita, Brno, Česká republika / Department of Czech Literature and Literary Studies, Faculty of Arts, Masaryk University, Brno, Czech Republic 
